\title{
Herpes simplex virus type 2 infection induces AD-like neurodegeneration markers in human neuroblastoma cells
}

\author{
Henrike Kristen $^{\text {a,b, }, ~}$, Soraya Santana ${ }^{a, 1,2}$, Isabel Sastre ${ }^{\mathrm{a}, \mathrm{b}, \mathrm{c}}$, Maria Recuero ${ }^{\mathrm{a}, \mathrm{b}}$, \\ Maria J. Bullido ${ }^{\mathrm{a}, \mathrm{b}, \mathrm{c}, *}$, Jesus Aldudo ${ }^{\mathrm{a}, \mathrm{b}, *}$ \\ ${ }^{a}$ Centro de Biologia Molecular "Severo Ochoa" (CSIC-UAM), Universidad Autonoma de Madrid, Madrid, Spain \\ ${ }^{\mathrm{b}}$ Centro de Investigacion Biomedica en Red sobre Enfermedades Neurodegenerativas (CIBERNED), Madrid, Spain \\ c Instituto de Investigacion Sanitaria "Hospital la Paz"(IdIPaz), Madrid, Spain
}

\section{A R T I C L E I N F O}

\section{Article history:}

Received 15 January 2015

Received in revised form 2 June 2015

Accepted 10 June 2015

Available online 18 June 2015

\section{Keywords:}

HSV-2 infection

Tau

Amyloid- $\beta$

Autophagy

Neurodegeneration

Alzheimer's disease

\begin{abstract}
A B S T R A C T
Herpes simplex virus (HSV) types 1 and 2 are neurotropic viruses that establish lifelong latent infections in neurons. Mounting evidence suggests that HSV-1 infection is involved in the pathogenesis of Alzheimer's disease (AD). The relationships between other herpesvirus infections and events associated with neurodegeneration have not, however, been extensively studied. The present work reports that HSV-2 infection leads to the strong accumulation of hyperphosphorylated tau and the amyloid- $\beta$ peptides $A \beta 40$ and $A \beta 42$ (all major pathological hallmarks of $A D$ ) in human SK-N-MC neuroblastoma cells. Infection is also associated with a marked reduction in the amount of $A \beta 40$ secreted and in the proteolytic fragments of the amyloid- $\beta$ precursor protein (APP) (secreted APP $\alpha$ and the $\alpha$-C-terminal fragment). These results indicate that HSV-2 infection inhibits the nonamyloidogenic pathway of APP processing and impairs $A \beta$ secretion in these cells. In addition, HSV-2 induces the accumulation of intracellular autophagic compartments containing $A \beta$ due to a failure in the late stages of autophagy. To our knowledge, this is the first report to show that HSV-2 infection strongly alters the tau phosphorylation state, APP processing, and autophagic process in human neuroblastoma cells, leading to the appearance of AD-like neurodegeneration markers.
\end{abstract}

(C) 2015 Elsevier Inc. All rights reserved.

\section{Introduction}

Alzheimer's disease (AD), the single most common cause of dementia, is characterized by massive neuronal damage leading to cerebral atrophy and the loss of cognitive function. The major neuropathological lesions of AD are brain $\beta$-amyloidosis and neurofibrillary degeneration; the former is characterized by plaques of extracellular amyloid- $\beta$ peptide $(A \beta)$ in the brain parenchyma and blood vessels, while the second involves the intracellular accumulation and aggregation of abnormally hyperphosphorylated tau protein (a microtubule-associated protein) in the form of neurofibrillary tangles (Braak and Braak, 1992). Two distinct forms of AD are recognized: familial and sporadic. Familial AD is caused by mutations

\footnotetext{
* Corresponding authors at: Centro de Biología Molecular "Severo Ochoa", Universidad Autónoma de Madrid, C/ Nicolás Cabrera 1, 28049 Madrid, Spain. Tel.: (+34) 91196 4674; fax: (+34) 911964420.

E-mail addresses: mjbullido@cbm.csic.es (M.J. Bullido), jaldudo@cbm.csic.es (J. Aldudo).

1 These authors contributed equally to this work.

2 Present address: BioPharma Division, Neuron Bio, Parque Tecnologico de Ciencias de la Salud, Edificio BIC, Avda. de la Innovación 1, 18,100 Armilla, Granada, Spain.
}

in the genes for amyloid- $\beta$ precursor protein (APP), presenilin- 1 , and presenilin-2. However, most cases of $\mathrm{AD}(\sim 99 \%)$ are of the sporadic type and usually involve people $>65$ years (Tanzi, 2012).

Sporadic AD is a highly complex disease for which neither the causal agent(s) nor the molecular mechanisms behind its pathogenesis are well known. A growing body of literature suggests, however, that cerebral infections may be risk factors for neurodegenerative disease, and certainly numerous studies have revealed an association between herpes simplex virus type 1 (HSV-1) and AD (Itzhaki, 2014; Piacentini et al., 2014). For example, HSV-1 DNA is present in the brains of a high proportion of people with $A D$ (Jamieson et al., 1991), mainly within amyloid plaques (Wozniak et al., 2009b), the virus has been shown capable of inducing the main hallmarks of AD pathology (Alvarez et al., 2012; Santana et al., 2012b; Wozniak et al., 2007, 2009a), and the analysis of data gathered in genome-wide association studies involving thousands of $\mathrm{AD}$ patients and controls identified a set of $\mathrm{AD}$-linked gene variants that might increase brain susceptibility to viral infections, particularly HSV-1 infection (Porcellini et al., 2010). Few studies, however, have focused on the role of other herpesviruses in $A D$, even though 5-herpes simplex virus type 2 (HSV-2), cytomegalovirus (CMV), human herpes virus 6 , varicella-zoster virus and 
Epstein-Barr virus (EBV)-have been detected in the brains of elderly individuals and AD patients (Carbone et al., 2014; Hemling et al., 2003; Lin et al., 2002).

Like HSV-1 (which causes cold sores), HSV-2 (which causes genital herpes) belongs to the alpha-herpesvirus subfamily. These viruses can reach the sensory neurons that innervate the site of primary infection, and establish lifelong latent infections. Reactivation from the latent state causes recurrent disease, which is particularly common in immunocompromised hosts (Steiner and Benninger, 2013). A recent study estimates $57 \%$ of US adults to be infected with HSV-1 and 17\% with HSV-2 (Koelle and Corey, 2008). It is well known that HSV-2 can infect the brain and cause neurological problems such as encephalitis and meningitis in neonates and encephalitis in adults (Berger and Houff, 2008). HSV-2 DNA, however, is found in the brains of far fewer people than HSV-1 DNA (both in those with AD and age-matched controls) (Lin et al., 2002). There are few comparative studies of HSV-1 and HSV-2 central nervous system infections, but it has traditionally been thought that HSV-2 causes fewer cases of herpes simplex encephalitis in adults than HSV-1 ( $\sim 10 \%$ compared to $\sim 90 \%$ ) (Berger and Houff, 2008). However, a recent report suggests that HSV-1 and HSV-2 account for similar numbers (Moon et al., 2014). These discordant findings may result from ethnic or regional differences between the study populations. In addition, the latter study has some limitations-all patients belong to a single center and it is a retrospective study with not well-defined criteria for categorization of neurological diseases. Further studies with well-designed prospective studies in multiple centers and regions are required to confirm that HSV-2 is a major cause of severe encephalitis in adults.

Our group and others have reported HSV-1 infection to modify tau phosphorylation (Alvarez et al., 2012; Wozniak et al., 2009a; Zambrano et al., 2008), APP proteolytic processing (De Chiara et al., 2010; Santana et al., 2012b; Wozniak et al., 2007), and autophagy (Gobeil and Leib, 2012; Santana et al., 2012a), all of which have been associated with the pathogenesis of AD. However, the effect of HSV-2 infection on these processes has not been extensively studied. The present work reveals that, like HSV-1 infection, HSV-2 infection can provoke the appearance of the neurodegeneration markers characteristic of AD in different cell models.

\section{Materials and methods}

\subsection{Drugs, plasmids, and antibodies}

Heparin $(10 \mu \mathrm{g} / \mathrm{mL})$, rapamycin $(0.2 \mu \mathrm{g} / \mathrm{mL})$, and bafilomycin $\mathrm{A} 1$ (100 nM) were purchased from Sigma. Leupeptin $(100 \mu \mathrm{M})$ was supplied by Roche. 4', 6-diamidino-2-phenylindole (DAPI; $5 \mu \mathrm{g} / \mathrm{mL}$ ) and ammonium chloride $\left(\mathrm{NH}_{4} \mathrm{Cl} ; 20 \mathrm{mM}\right)$ were obtained from Merck.

The GFP-light chain 3 (LC3) expression vector (pGFP-LC3) and the mCherry-GFP-LC3 construct (dtLC3) were kind gifts from T. Yoshimori and N. Mizushima (Kabeya et al., 2000), and T. Johansen (Pankiv et al., 2007), respectively. Rabbit anti-HSV glycoprotein B and $\mathrm{D}(\mathrm{gB} / \mathrm{gD})$ antibody was kindly provided by E. Tabares. Mouse anti-APP A4 antibody (clone 22C11) was purchased from Millipore (MAB348). Monoclonal anti-human $\beta$-amyloid protein [1-17] (clone 6E10) was supplied by Sigma (A1474). Rabbit anti-amyloid precursor protein, C-terminal, antibody, recognizing all APP carboxy-terminal fragments (CTFs), was purchased from Sigma (A8717). Rabbit polyclonal anti-A $\beta 40$ (44348A) and anti-A $\beta 42$ (44-344) unconjugated antibodies, (pS199), (pT205), (pT231), (pS404), and (pS422) tau polyclonal antibodies (44734G; 44738G; 44746G; 44758G, and 44764G) and tau (TAU-5) monoclonal antibody (AHB0042) were purchased from Life Technologies. Two antiLC3 antibodies were used: rabbit anti-LC3B from Sigma (L7543) and rabbit polyclonal anti-LC3 from MBL (PD014). Human CD63 antibody was obtained from the Developmental Studies Hybridoma Bank, University of Iowa (CD63, clone H5C6). Rabbit serum anti-GFP came from Life Technologies (A-6455). Mouse monoclonal antitubulin antibody was supplied by Sigma (T5168). The secondary antibodies used for immunostaining were horseradish peroxidasecoupled antibodies (Vector), or antibodies labeled with Alexa Fluor 488 or 555 dyes (Invitrogen).

\subsection{Cell culture}

Vero and SK-N-MC (human neuroblastoma) cell lines used in this work were purchased from the American Type Culture Collection. SK-N-MC cells stably expressing human APP (SK-APP) (Recuero et al., 2004) or GFP-LC3 (SK-LC3) (Santana et al., 2012b) were produced in-house. The SK-N-MC cells were grown as monolayers in minimal Eagle's medium supplemented with $10 \%$ heat-inactivated fetal calf serum, $2 \mathrm{mM}$ glutamine and $50 \mu \mathrm{g} / \mathrm{mL}$ gentamicin. Vero cells were passaged in Dulbecco's modified Eagle medium supplemented with $10 \%$ fetal calf serum, $2-\mathrm{mM}$ glutamine, and $50-\mu \mathrm{g} / \mathrm{mL}$ gentamicin. All cells were grown at $37^{\circ} \mathrm{C}$ in a $5 \% \mathrm{CO}_{2}$ atmosphere.

\subsection{HSV-2, infection, plaque assays, and viral DNA quantification}

HSV-2 strain 333 was propagated on a monolayer of Vero cells as previously described (Carrascosa et al., 1982) and stored at $-70{ }^{\circ} \mathrm{C}$. The infectious titers of HSV-2 were determined by plaque assay (Santana et al., 2012b). For infection experiments, cells were grown in 6-well plates (for Western blot assays) or 24-well plates with coverslips (for immunofluorescence assays). When the cells reached $70 \%-80 \%$ confluence they were exposed to HSV-2 at $37{ }^{\circ} \mathrm{C}$ for 1 hour. Mock infections were performed using a virus-free suspension. Unbound virus was removed and the cells incubated in complete medium. Times and multiplicities of infection (expressed as plaqueforming units per cell [pfu/cell]) are as indicated in each experiment. Viral DNA levels were quantified by real-time quantitative polymerase chain reaction in the presence of SYBR Green, using primers specific for the overlapping region of UL18 and UL19 genes of HSV-2 (5'-GCTCCCCCCCGTGGA- $3^{\prime}$ and 5'-AGGATTTCGCGCAGGTGAT-3'), employing an ABI Prism 7900HT SD system (Applied Biosystems). The quantification of human genomic DNA was performed using an Assay-on-Demand probe specific for the glyceraldehyde-3-phosphate dehydrogenase housekeeping gene (Applied Biosystems; item nu Hs99999905_m1). The quantification results were calculated as viral DNA copy numbers per ng of genomic DNA.

\subsection{Immunofluorescence analysis}

Cells grown on coverslips were fixed in $4 \%$ formaldehyde and incubated with the appropriate primary and secondary antibodies. DAPI was added 10 minutes before the end of the procedure to visualize the nuclei. GFP-LC3 and dtLC3 imaging was performed in the same way but without antibody incubations. All cells were examined using a Zeiss Axiovert 200 fluorescence microscope or a Zeiss LSM710 vertical confocal microscope equipped with a $63 \times$ oilimmersion objective. Pictures were taken with a Spot RT slider digital camera (Diagnostic) using Metamorph 5.07 (Universal Imaging Corporation) or ZEN 2012 (Carl Zeiss Microscopy GmbH) imaging system software, and processed using Adobe Photoshop CS4.

\subsection{Western blot analysis}

For Western blot assays, cells were treated with lysis buffer (50-mM Tris- $\mathrm{HCl} \mathrm{pH} \mathrm{7.6,} \mathrm{300-mM} \mathrm{NaCl,} \mathrm{and} \mathrm{0.5 \%} \mathrm{Triton} \mathrm{X-100)} \mathrm{con-}$ taining a protease inhibitor cocktail (Complete Mini, Roche) and incubated for 30 minutes at $4^{\circ} \mathrm{C}$. For tau analysis, cells were lysed in 
radioimmunoprecipitation assay buffer (10-mM Tris- $\mathrm{HCl} \mathrm{pH}$ 7.5, 50$\mathrm{mM} \mathrm{NaCl}, 0.2 \%$ sodium deoxycholate, $1 \%$ Nonidet $\mathrm{P}-40 \%$, and $0.1 \%$ sodium dodecyl sulfate) containing protease and phosphatase inhibitor cocktails (PhosSTOP, Roche), and incubated for 30 minutes at $4{ }^{\circ} \mathrm{C}$. Lysates were centrifuged at $13,000 \mathrm{~g}$ for 15 minutes at $4{ }^{\circ} \mathrm{C}$. For endogenous LC3 analysis, lysates were prepared as described elsewhere (Santana et al., 2012b). Determinations of protein content were performed using the bicinchoninic acid assay (Pierce). For secreted APP analysis, the conditioned medium was treated with a protease inhibitor cocktail and concentrated 10 fold. Cell lysates and medium were mixed with Laemmli buffer, sonicated, and heated for 5 minutes at $100{ }^{\circ} \mathrm{C}$. After electrophoretic separation, the gels were blotted onto a nitrocellulose membrane and stained with the appropriate antibodies. A peroxidase-coupled antibody was used as a secondary antibody. Detection by enhanced chemiluminescence was performed using ECL Western blotting detection reagents (Amersham Biosciences) according to the manufacturer's instructions.

\subsection{Measurement of secreted $A \beta$}

SK-APP cells were infected with HSV-2 and the medium later assayed for human $A \beta 40$ using a commercial sandwich enzymelinked immmunosorbent assay kit (Life Technologies) as described elsewhere (Santana et al., 2012b).

\subsection{Secretase activity assays}

$\alpha$ - and $\beta$-secretase activity was determined using commercial kits (R\&D Systems) according to the manufacturer's instructions, as described elsewhere (Santana et al., 2012b).

\subsection{Statistical analysis}

Graph values are expressed as mean \pm standard error of the mean. Differences between groups were analyzed using the 2tailed Student $t$ test. Significance was recorded at $p<0.05\left(^{*}\right), p<$ $0.01\left(^{* *}\right)$, and $p<0.001\left(^{* * *}\right)$. Before analysis, the largest and the smallest variances were tested for homogeneity using the F-test.

\section{Results}

\subsection{HSV-2 induces the accumulation of hyperphosphorylated tau}

Before all else, the HSV-2 infection parameters for the SK-N-MC cells were optimized. In this cell model, HSV-2 establishes a lytic replication cycle resulting in cell lysis $\sim 20-22$ hours after infection. In this work, all infections were performed at a moi of $10 \mathrm{pfu} /$ cell because this viral dose guarantees that almost all cells become infected, as revealed by confocal images of HSV-2-infected cells, visualized via the use of an antibody that recognizes glycoproteins $B$ and D of the virus (Supplementary Fig. 1).

Immunofluorescence analysis was used to determine whether HSV-2 infection modifies the phosphorylation state of tau in SK-NMC cells. For this, the Tau-5 antibody, which reacts with a phosphorylation-independent epitope, and the phosphorylationsensitive antibodies ser199, thr205, thr231, ser404, and ser422 were used. In noninfected cells, phosphorylation-sensitive antibodies stained the cytoplasm only weakly (Fig. 1A). It should be noted that, except for the ser404 epitope, stronger immunoreactivity was observed in mitotic cells (Supplementary Fig. 2); this is consistent with the results of other authors (Delobel et al., 2002) who reported that the abnormal tau-phosphorylation characteristic of $\mathrm{AD}$ also occurs during mitosis. When the cells were exposed to HSV-2, all the tested epitopes revealed an accumulation of phosphorylated tau (Fig. 1A). Western blot analysis was used to quantify the effects of HSV-2 infection on tau phosphorylation (Fig. 1B). As suggested by the immunofluorescence experiments, a significant increase of phosphorylated tau levels was observed in all the examined epitopes compared to noninfected cells (Fig. 1C). However, the infected cells actually showed a small reduction in total tau levels, ruling out the possibility that the increase in phosphorylated tau induced by HSV-2 was due to an increase in tau content.

HSV-1 infection has previously been shown to induce the intranuclear accumulation of hyperphosphorylated tau at viral replication sites (Alvarez et al., 2012). In the present work, when the staining patterns of the phosphorylation-sensitive antibodies and the nuclear counterstain DAPI in HSV-2-infected cells were examined by confocal microscopy, the structures stained by the ser199, thr231, and ser404 antibodies were seen to fill the large, dark holes that appear in the nuclei of infected cells (Supplementary Fig. 3). Numerous reports have revealed that dark areas of DAPI staining coincide with the location of the viral replication centers (Calle et al., 2008; Wilcock and Lane, 1991). These data therefore indicate that some of the hyperphosphorylated tau accumulates within the nuclei of HSV-2-infected cells.

\subsection{HSV-2 modifies the levels of $A \beta$ and APP proteolytic fragments}

Tests were next performed to determine whether HSV-2 also modulates APP processing. It has previously been shown that HSV-1
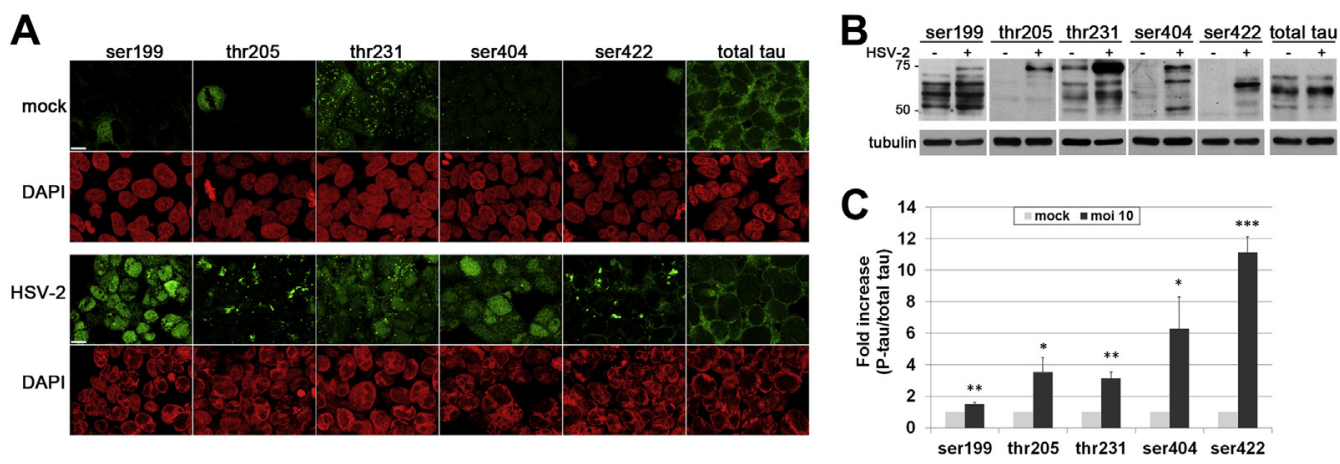

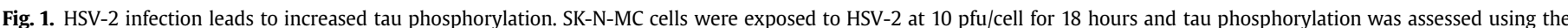

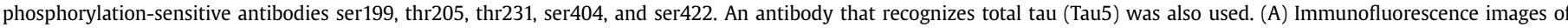

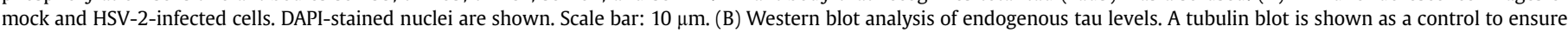

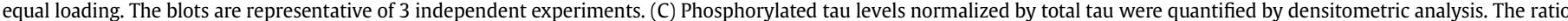

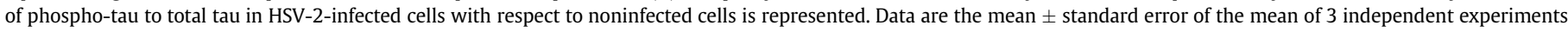
$\left({ }^{*} p<0.05 ;{ }^{* *} p<0.01 ;{ }^{* * *} p<0.001\right)$. Abbreviations: DAPI, $4^{\prime}, 6$-diamidino-2-phenylindole; HSV-2, herpes simplex virus type 2 . 
causes the accumulation of intracellular $A \beta$ and to intensely inhibit its secretion (Santana et al., 2012b). As a first step, the $A \beta$ levels in the SK-N-MC cell line overexpressing the human APP protein (SKAPP) were examined by immunofluorescence. Intracellular $A \beta$ was undetectable in noninfected cells at both test times (Fig. 2A). In contrast, HSV-2 infection induced a strong elevation of both the main intracellular species of $A \beta$ peptide at 18 hours postinfection (hpi). In fact, this increase began at least at $6 \mathrm{hpi}$ (Fig. 2B), indicating that HSV-2 induces $A \beta$ accumulation early in infection. Similar results were obtained in Vero cells (Supplementary Fig. 4), another cell type in which HSV-1 has been reported to increase intracellular $A \beta$ levels (Wozniak et al., 2011). The A $\beta 40$ content of the extracellular medium of infected and noninfected SK-APP cells was then determined by enzyme-linked immmunosorbent assay. When these cells were infected with HSV-2, the A $\beta 40$ levels fell drastically (by $>4$ fold). Neither $A \beta 42$ nor intracellular $A \beta$ was detectable by this assay. To confirm that the reduction in $A \beta 40$ was provoked by HSV-2 infection, the cells were treated with heparin, an inhibitor of herpesvirus entry; this completely stopped the reduction in $A \beta 40$ previously recorded (Fig. 2C). Heparin treatment drastically reduced the levels of HSV-2 DNA demonstrating that heparin efficiently blocked viral replication in SK-APP cells (>99\%; Fig. 2D), thus ensuring that the effect of heparin on $A \beta$ secretion was mediated by inhibition of HSV-2 infection.

To investigate how HSV-2 infection impacts APP processing, the activities of $\alpha$ - and $\beta$-secretases were recorded using specific fluorescent activity assays. Analysis of HSV-2-infected cells revealed their $\alpha$-secretase activity to be reduced by $40 \%$ compared to noninfected cells. In contrast, no changes were recorded in $\beta$-secretase activity after HSV-2 infection (Fig. 3A). Consistent with these data, when the generation of products resulting from $\alpha$-secretase activity was examined by Western blotting, HSV-2 infection led to a dramatic reduction in secreted SAPP $\alpha$ (Fig. 3B) and $\alpha-C T F$ (Fig. 3C). No significant differences were detected in APP expression in the cells after infection with HSV-2 (Fig. 3D), ruling out that the alteration of the different APP proteolytic products was due to any change in the actual amount of APP available.

Taken together, these findings are consistent with those obtained in HSV-1-infected cells and suggest that infection with herpesviruses strongly modifies APP processing and A $\beta$ levels.

\subsection{Inhibition of autophagic flux in HSV-2-infected cells}

HSV-1 has been reported to strongly alter autophagy, a major degradative pathway of the lysosomal system known to be much impaired in AD. The microtubule-associated protein 1 LC3 is synthesized as a precursor (proLC3) which is proteolytically processed into the cytosolic LC3-I isoform. On activation of autophagy, LC3-I is modified into the phosphatidylethanolamine-conjugated form, LC3II, which specifically binds to autophagic membranes. Changes in LC3 provide a very useful marker of autophagy and can be monitored by immunofluorescence and Western blotting (Klionsky et al., 2012). To examine the effects of HSV-2 infection on autophagy, the endogenous LC3 levels of SK-N-MC cells were determined. Immunofluorescence

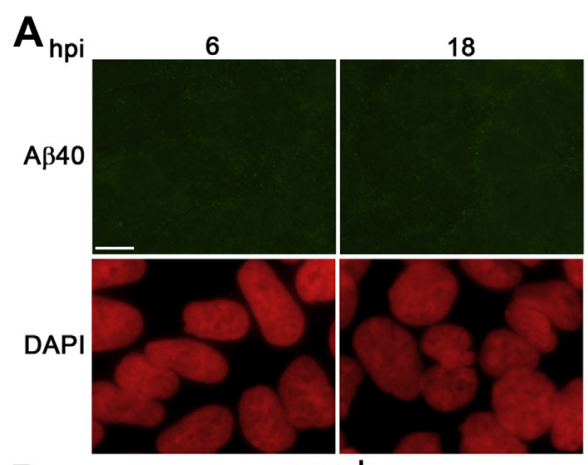

B

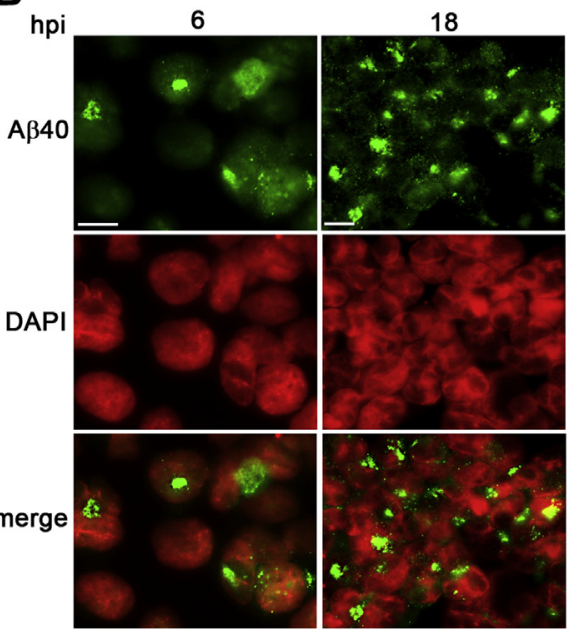

HSV-2

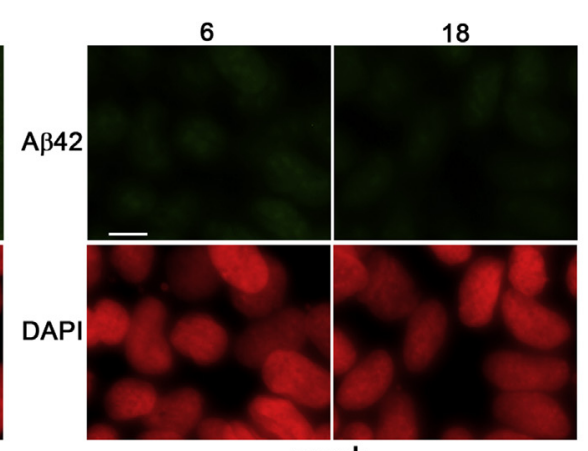

mock

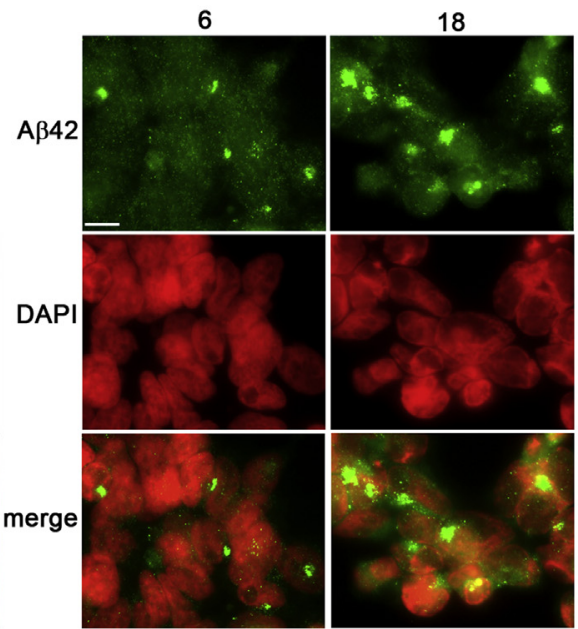

HSV-2
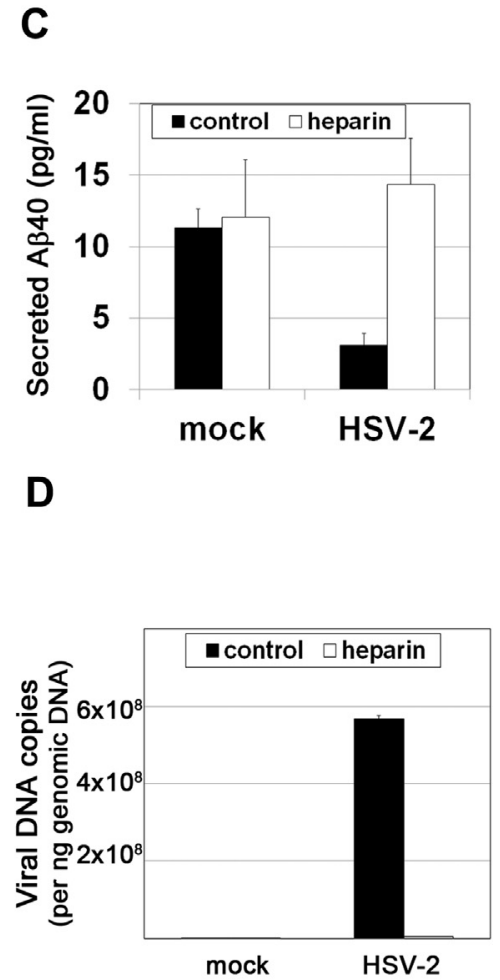

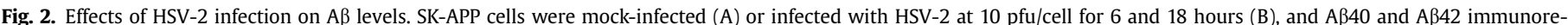

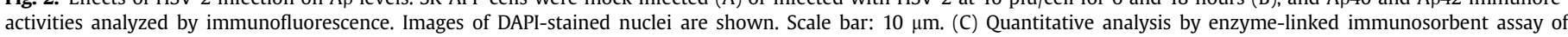

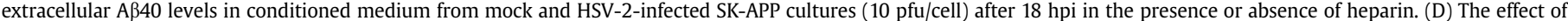

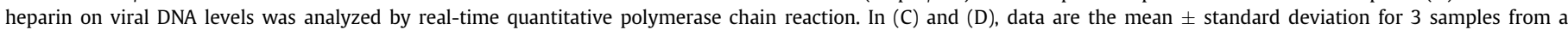

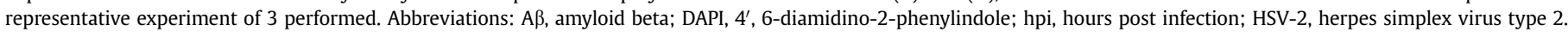


A

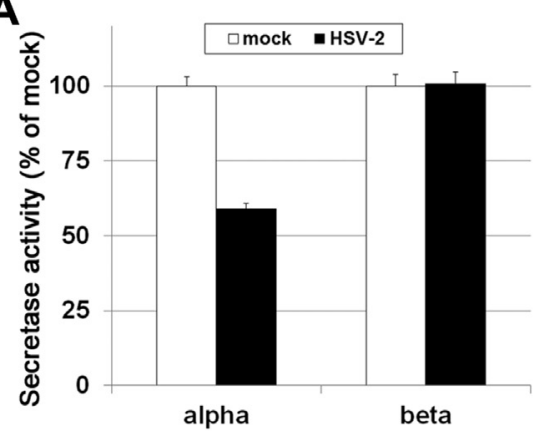

B

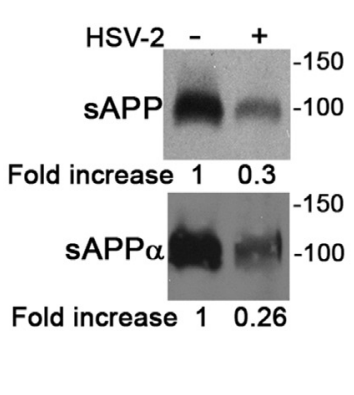

C

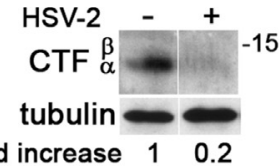

D

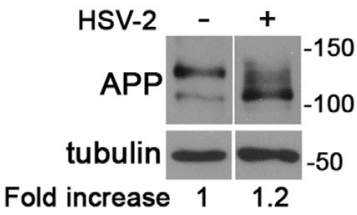

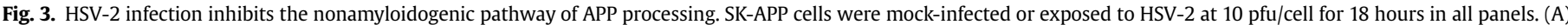

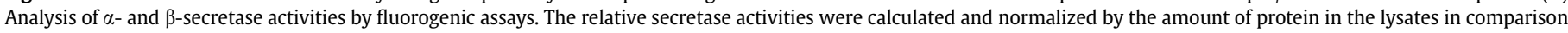

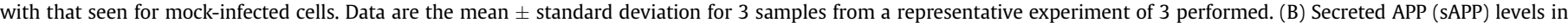

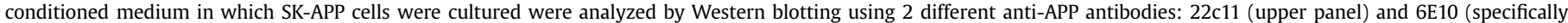

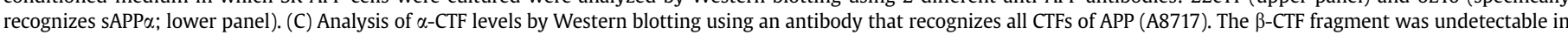

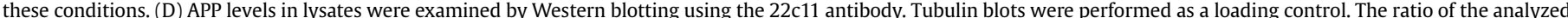

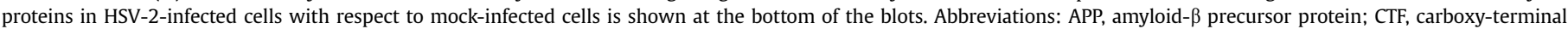
fragment; HSV-2, herpes simplex virus type 2 .

analysis showed HSV-2 to induce a strong increase in LC3 immunoreactivity, suggesting an accumulation of autophagic compartments in infected cells (Fig. 4A). To better quantify the effects of infection, the lipidation of LC3 was monitored by Western blotting. Consistent with the results obtained for the immunofluorescence experiments, endogenous LC3-II levels were markedly increased in cells exposed to HSV-2 at 18 hpi (Fig. 4B). In addition, the distribution of LC3 in SK-NMC cells stably expressing the GFP-LC3 fusion protein (SK-LC3) was studied by fluorescence microscopy. In noninfected cells, few GFPLC3 spots were observed. In contrast, GFP-LC3-positive structures accumulated in HSV-2-infected cells (Supplementary Fig. 5A). When the GFP-LC3 levels were analyzed by Western blotting, HSV-2 was seen to provoke a strong accumulation of the autophagy-associated isoform GFP-LC3-II (Supplementary Fig. 5B). These results were reproduced in Vero cells (which are also susceptible to HSV infection) (Supplementary Fig. 6A and B).

Increased LC3-II levels could stem from the overactivation of autophagy or reduced autophagic turnover due to defects in the late stages of autophagic degradation. Determining LC3-II levels in the presence of the lysosomal inhibitors leupeptin (a lysosomal protease

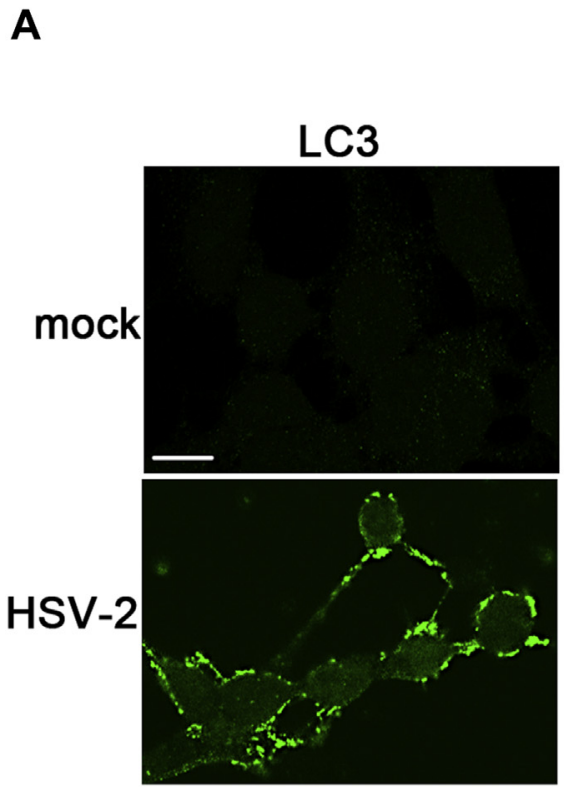

B
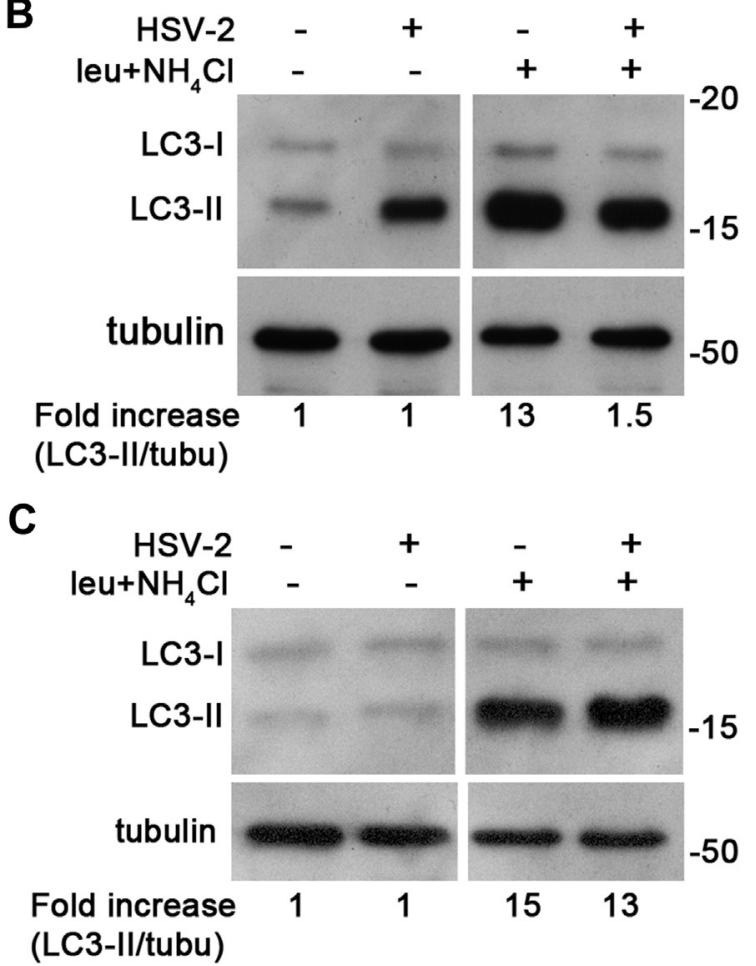

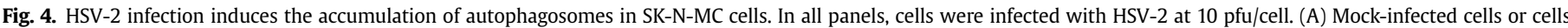

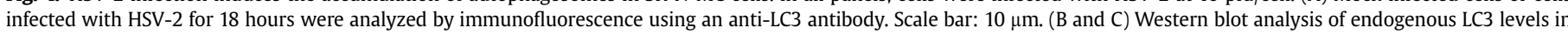

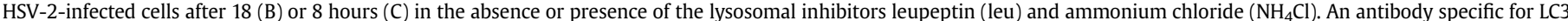

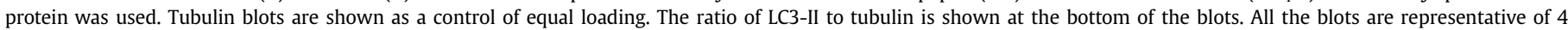
independent experiments. Abbreviations: LC3, light chain 3; HSV-2, herpes simplex virus type 2. 
inhibitor) and ammonium chloride (a lysosomotropic agent that neutralizes the acidic lysosomal $\mathrm{pH}$ ) by Western blotting is a wellestablished means of measuring autophagic flux. With the lysosomal inhibitor treatment, endogenous LC3-II levels dramatically increased in noninfected SK-N-MC cells ( $>10$ fold) indicating a functional lysosomal degradation of LC3-II. However, when cells were exposed to HSV-2, a modest increase in LC3-II was recorded in the presence of lysosomal inhibitors ( 1.5 fold) during the late stages of infection (18 hpi), suggesting autophagosome turnover becomes blocked in HSV-2-infected cells (Fig. 4B). When the effect of lysosomal inhibitors was analyzed in SK-LC3 cells, similar results were obtained (Supplementary Fig. 5B). These findings, which were also reproduced in Vero cells (Supplementary Fig. 6B), indicate that only some of the LC3-II molecules are degraded by lysosomes in HSV-2infected cells, resulting in the accumulation of autophagosomes. In contrast, when these experiments were performed in the early stages of infection (8 hpi) in SK-N-MC (Fig. 4C) and Vero (Supplementary Fig. 6C) cells, treatment with lysosomal inhibitors caused a similar increase in endogenous LC3-II levels in both noninfected and HSV-2infected cells, indicating that HSV-2-infected cells experience unaltered autophagic flux early in infection.

The tandem fluorescent-tagged LC3 construct-the mCherryGFP-LC3 reporter (dtLC3) - was used to confirm the inhibition of autophagic flux in HSV-2-infected cells. The acidic lysosomal environment quenches GFP fluorescence but not mCherry fluorescence. Therefore, when autophagosomes fuse with lysosomes, GFP fluorescence from dtLC3 is lost and only red fluorescence is recorded. In noninfected SK-N-MC cells, and cells treated with rapamycin to induce autophagy, yellow and red vesicles appeared, revealing the formation of autophagosomes and autolysosomes and thus demonstrating functional autophagy. A significant increase in the number of vesicles was seen in rapamycin-treated cells, consistent with the activation of autophagy induced by the drug. In contrast, a marked increase in the number and proportion of yellow puncta was observed in cells infected with HSV-2 at 18 hpi compared with nontreated cells. These effects are analogous to the changes produced by lysosomal alkalinization induced by bafilomycin A1 (Fig. 5) and are indicative of accumulation of autophagosomes, probably caused by a failure in the autophagosome-lysosome fusion process.

Taken together, these results indicate that HSV-2 blocks autophagic flux in the late stages of the viral replication cycle.

\subsection{HSV-2 induces the accumulation of $A \beta$ in autophagosomes}

To further investigate the relationship between autophagosome accumulation and alterations in APP processing, the intracellular distribution of $A \beta$ was monitored in HSV-2-infected cells by confocal microscopy. To this end, SK-APP cells were stained for A $\beta$, along with markers for autophagic compartments (LC3), and late endosomes and/or lysosomes (CD63). A $\beta$ and LC3 immunoreactivities were almost undetectable in noninfected cells, whereas CD63 showed a characteristic punctate cytosolic pattern (Fig. 6A). Analysis of the confocal images revealed $A \beta$ structures to colocalize with endogenous LC3 in cells exposed to HSV-2, indicating that A $\beta$ was located in autophagic compartments (Fig. 6B). The colocalization of

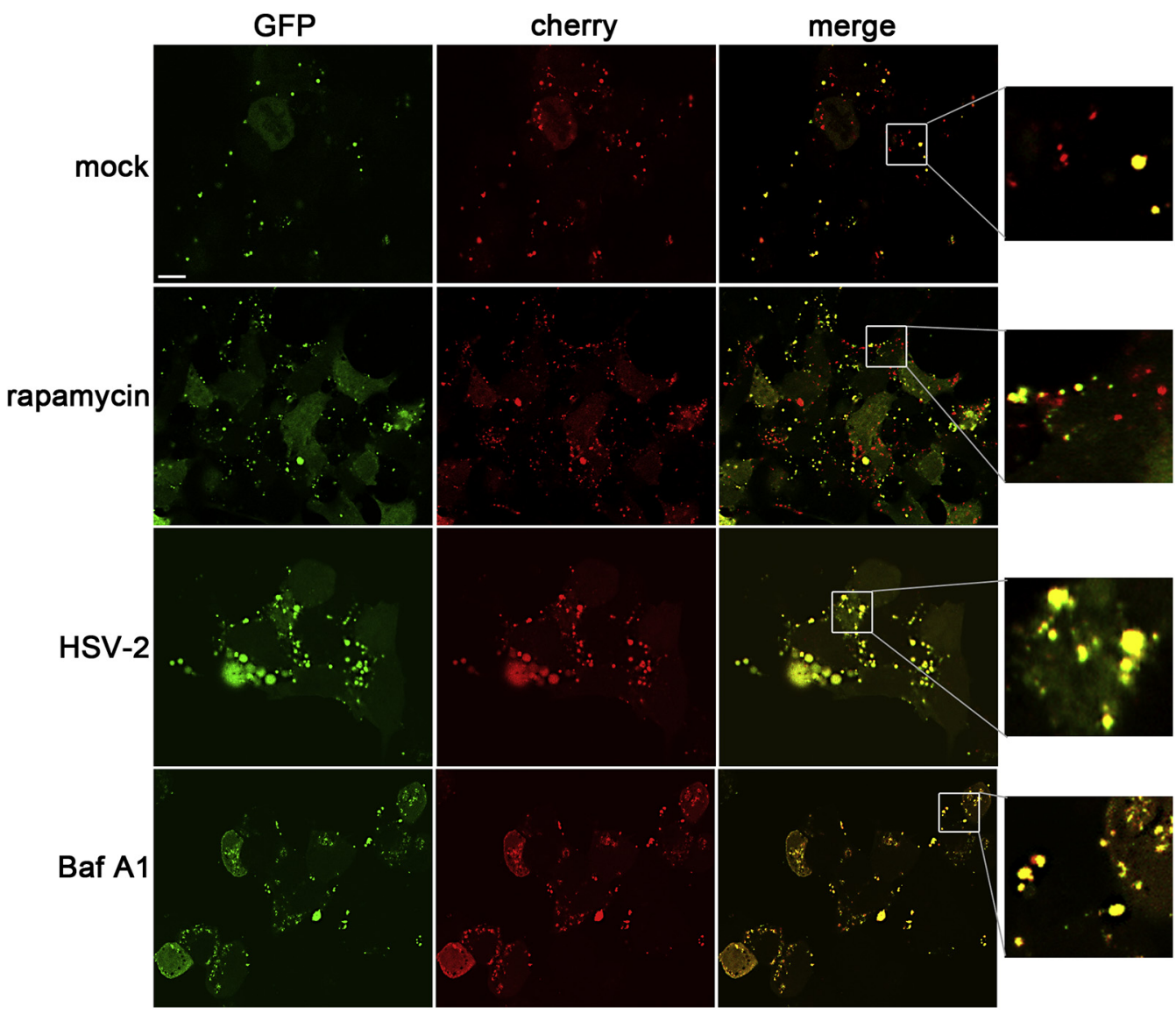

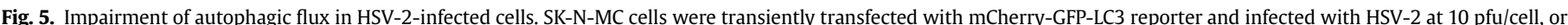

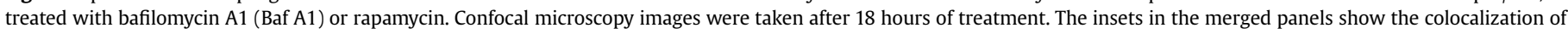
green and red signals under the different conditions assayed. Scale bar: $10 \mu \mathrm{m}$. Abbreviation: HSV-2, herpes simplex virus type 2 . 
$\mathrm{A} \beta$ with the lysosomal marker CD63 was then monitored. Lysosomes are the destiny organelles of the autophagic pathway where the vesicular contents are degraded. When SK-APP cells were infected with HSV-2, no colocalization of CD63 with either $A \beta$ isoform was detected (Fig. 6C).

Taken together, these results show that $A \beta$ does not reach the lysosomal compartment resulting in the accumulation of $A \beta$ in autophagosomes, confirming a failure in autophagic flux in HSV-2infected cells.

\section{Discussion}

AD is a multifactorial disorder that apparently involves different etiopathogenic mechanisms. One of the factors involved may be infectious agents that are able to colonize the brain and thus escape the immune response. Infection by different members of the herpesvirus family may be a risk factor for AD. These viruses are highly prevalent in the human population and the infection rate increases with age, they can infect neurons, and they establish lifelong latent infections that cannot be removed by the immune system. Most of the studies have focused on the relationship between HSV-1 and AD but with nearly 70\% genetic homology and a very similar transcription map, HSV-2 is a closely related virus (Aguilar et al., 2006), and it would not be surprising to discover that HSV-2 infection has effects similar to HSV-1 infection on processes whose modification has been related to neurodegeneration. Certainly it is well known that HSV-2 can infect the brain and that it is associated with neurological alterations (Steiner and Benninger, 2013), but its impact on the appearance of $\mathrm{AD}$-like neurodegeneration markers has not been studied in depth. In this report, HSV-2 infection is

A

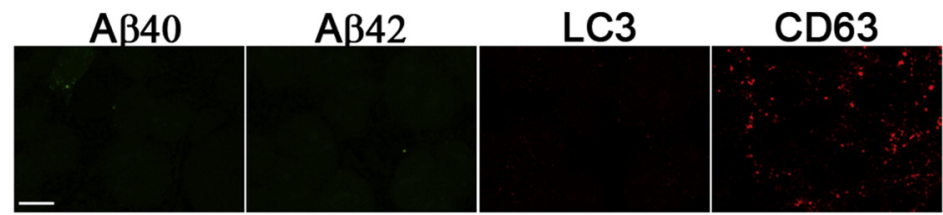

B

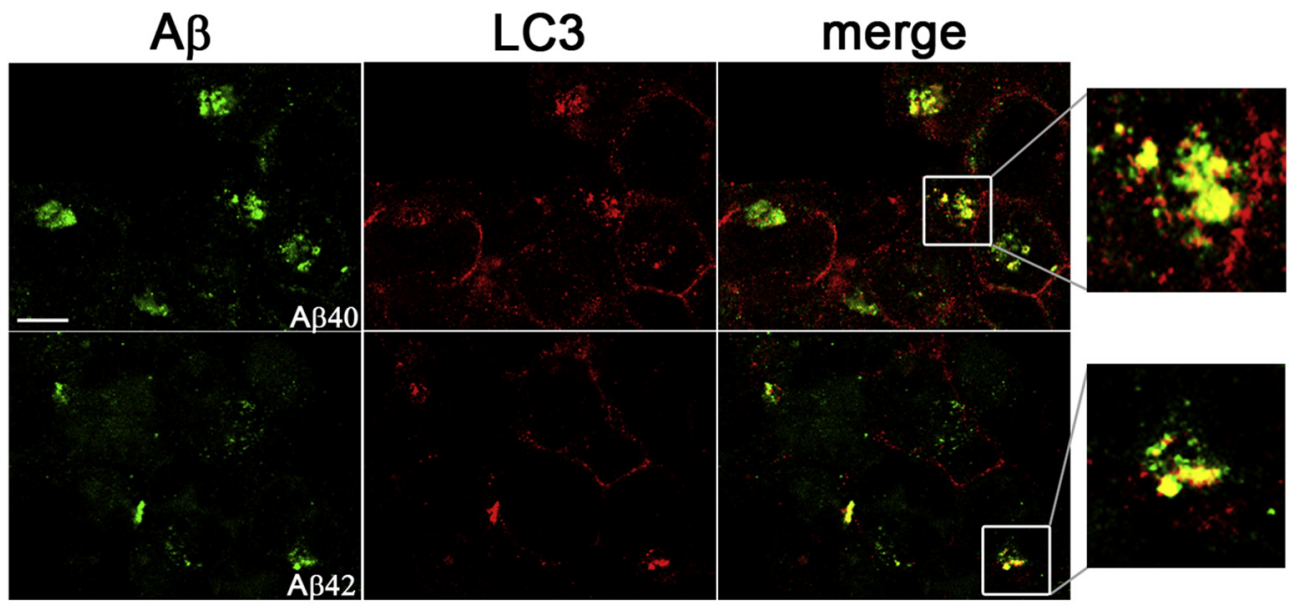

C
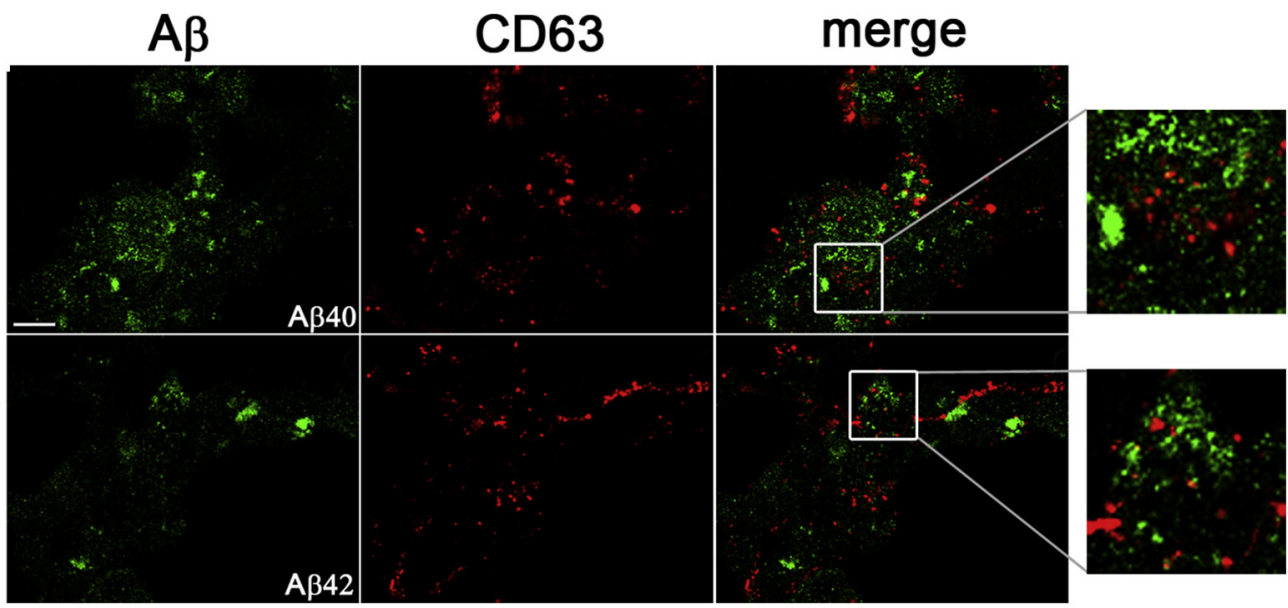

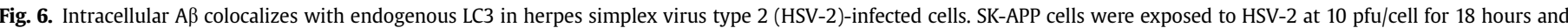

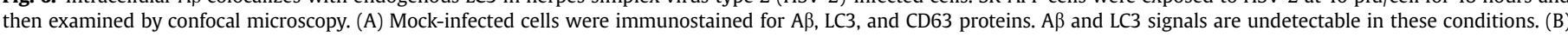

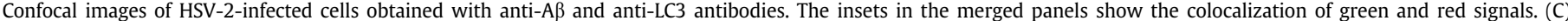

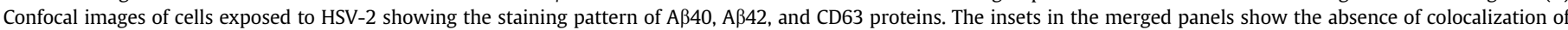
green and red signals. Scale bar: $10 \mu \mathrm{m}$. Abbreviations: A $\beta$, amyloid beta; LC3, light chain 3 . 
shown to cause the main pathological alterations found in AD brains, supporting the hypothesis of an active role for this and perhaps other herpesviruses in $\mathrm{AD}$.

Neurofibrillary degeneration is a major neuropathological hallmark of AD. It results from the aggregation of abnormally phosphorylated tau protein as paired helical filaments (PHFs). Tau is found in the adult brain in 6 isoforms, generated by alternative splicing, ranging from 48 to $68 \mathrm{kDa}$ in molecular weight (Goedert and Jakes, 1990). In the present work, a complex band pattern characteristic of the expression of all 6 tau isoforms was obtained in SK-N-MC cells. In cell cultures exposed to HSV-2, all 5 examined epitopes reported an increase in phosphorylated tau levels, and the band profile of phospho-tau species became very complex. The present findings are similar to those reported in $\mathrm{AD}$ and other tauopathies, in which a band profile of phospho-tau strongly dependent on the phospho-specific tau antibody used is reported (Puig et al., 2005; Santpere et al., 2006). Importantly, all the sites examined in the present work are reported to be hyperphosphorylated in PHF tau in AD brains (Lovestone and Reynolds, 1997), which supports the role of herpesviruses in promoting aberrant tau phosphorylation in $\mathrm{AD}$. In addition, confocal analysis showed that some of the phosphorylated tau species induced by HSV-2 accumulate in the nucleus. Consistent with these results, previous work performed at our laboratory has shown hyperphosphorylated tau to accumulate in the viral replication compartments in the nucleus of HSV-1-infected cells (Alvarez et al., 2012). The effect of nuclear accumulation of phosphorylated tau induced by HSV might not be related to tangle formation. However, tau phosphorylation may determine the recruitment of tau to the nucleus, or may alter tau activity to promote the viral replication and/or transcription processes in neuronal cells, with the consequence of neurodegeneration. Alternatively, cellular proteins may be targeted to damaged viral DNA that arises during replication (Mohni et al., 2010). In this respect, a role of tau in neuronal DNA protection has been recently described (Sultan et al., 2011). Further studies are required to examine the role of nuclear phosphorylated tau in herpesvirus infections. In addition, HSV-2 also increases tau phosphorylation in the cytoplasm of infected cells. The accumulation of hyperphosphorylated tau in the cell body could contribute to the generation of PHFs and, therefore, to the neurodegeneration characteristic of $\mathrm{AD}$. The functional significance of these differential phosphorylation events is unclear but suggests that tau protein is a relevant target of HSV-2 infection and may play a functional role in the infection process.

It is well established that the buildup of intracellular $A \beta$ is one of the earliest events in the pathogenesis of AD (LaFerla et al., 2007). HSV-2 infection was found to increase intracellular $A \beta$ levels and to intensely inhibit $A \beta$ secretion. $A \beta$ accumulation has also been shown to be induced by other brain pathogens related to AD, supporting the infectious hypothesis (Miklossy, 2011). Recent work has shown that $A \beta$ may act as a defensive molecule of the innate immune system, with activity against several bacteria and yeasts (Soscia et al., 2010), influenza A virus (White et al., 2014), and HSV-1 (Bourgade et al., 2014). This role is consistent with the idea that viral infections are associated with the etiology and pathogenesis of AD. Herpesviruses and other infectious agents might trigger an overproduction of $A \beta$ peptides, which might contribute to amyloid plaque formation and the progression of $\mathrm{AD}$.

$\beta$-secretase is the initiating and rate-limiting enzyme in the production of $A \beta$ (Cai et al., 2001). There are numerous reports that an increase in the activity of $\beta$-secretase leads to the accumulation of intracellular $A \beta$, contributing to $A D$ pathogenesis. In the present work, no significant changes were seen in $\beta$-secretase activity in HSV-2-infected cells. However, HSV-2 induced a potent inhibition of $\alpha$-secretase activity along with a strong reduction in the levels of the proteolytic products $\alpha$-CTF and SAPP $\alpha$. This indicates a downregulation of the nonamyloidogenic pathway of APP processing in infected cells. Finally, the accumulation of intracellular A $\beta$ in LC3positive compartments strongly suggests a failure in $A \beta$ degradation in the autophagic compartments induced by HSV-2. To test this hypothesis, the effects of HSV-2 on autophagy were analyzed and it was found that HSV-2 induced a marked increase in the levels of the autophagosome-associated LC3-II isoform, resulting in the accumulation of autophagic compartments in infected cells. Autophagy defects might play a role in neurodegenerative disorders, especially in AD. Indeed, large accumulations of autophagic compartments in AD brains have been reported (Nixon et al., 2005), indicating impaired clearance of autophagosomes rather than any strong induction of autophagy (Nixon and Yang, 2011). In line with these findings, the strong accumulation of autophagosomes induced by HSV-2 seems to be due to a failure in the autophagic flux. This in turn seems to be provoked by a defect in autophagosome-lysosome fusion. Interference with the late stages of autophagy might therefore enhance the accumulation of $A \beta$ in autophagosomes in infected cells. Our group has previously reported that HSV-1 induces similar alterations in APP processing and autophagy pathways (Santana et al., 2012a, 2012b). Taken together, the present findings suggest that the intracellular accumulation of $A \beta$ caused by HSV-2 infection is produced by the inhibition of $A \beta$ secretion and the failure of $A \beta$ degradation by lysosomes. The inhibition of the nonamyloidogenic pathway might also contribute to this accumulation.

Numerous experimental findings suggest the implication of HSV-1 infection in AD pathogenesis [see recent reviews by Itzhaki, 2014; Piacentini et al., 2014] and there is growing evidence that other herpesviruses might be involved. The presence of IgM antiHSV antibodies (recognizing HSV-1 and HSV-2 antigens) in serum-a marker of HSV reactivation-was found to be correlated with an increased risk of developing AD (Letenneur et al., 2008; Lovheim et al., 2014). Recently, EBV and human herpes virus 6 DNA positivity, along with CMV and EBV IgG plasma levels, were also associated with cognitive decline and progression to AD in the elderly (Carbone et al., 2014). Finally, several studies have shown the viral load of different herpesvirus to be associated with cognitive impairment in elderly individuals with vascular risk (Katan et al., 2013; Strandberg et al., 2003, 2005), and a recent study showed that accumulated infections, including those of HSV-1 and CMV, might be associated with AD (Bu et al., 2014). It has been widely demonstrated that inflammation is strongly associated with neurodegeneration and cognitive impairment (Schott and Revesz, 2013). It may be that successive cycles of latency-reactivation of these viruses trigger systemic immune responses and induce inflammatory processes that may subsequently produce cognitive decline. Moreover, when these viruses reach the brain, they may also induce neuroinflammation, which would contribute to neuronal death. In addition, during chronic exposure to HSV-1 and/ or HSV-2 infection, virally-induced $A \beta$ and hyperphosphorylated tau might accumulate and persist in brain tissue, triggering a cascade of events leading to neurodegeneration. Consistent with this hypothesis, asymptomatic reactivation episodes promoting neuroinflammation and neurodegenerative markers have been reported in a mouse model of latent infection of HSV-1 (Martin et al., 2014). Finally, HSV-2 infection might potentiate the brain damage caused by HSV-1 or another pathogenic agent, perhaps by enhancing reactivation in the brain. However, the mechanisms responsible for the association between herpesvirus infections and $A D$ remain unclear.

In summary, the present observations show that infection with HSV-2, like HSV-1, induces the main AD-like neurodegeneration markers in human neuroblastoma cells, including tau hyperphosphorylation, anomalies in APP proteolytic processing 
leading to intracellular $A \beta$ accumulation, and impairment of autophagy. These findings strongly support the idea that herpesviruses are involved in the pathogenesis of sporadic AD.

\section{Disclosure statement}

Soraya Santana is currently employed by the commercial company BioPharma Division, Neuron Bio, Granada, Spain. The other authors declare no actual or potential conflicts of interest.

\section{Acknowledgements}

This work was supported by grants from the Ministerio de Economía y Competitividad (SAF2010-15558; URL: http://www. mineco.gob.es/portal/site/mineco) and Centro de Investigacion Biomedica en Red sobre Enfermedades Neurodegenerativas CIBERNED (PI2010/09-8; URL: http://www.ciberned.es). The authors thank Drs. T. Yoshimori and N. Mizushima for providing the GFP-LC3 expression vector; Dr. T. Johansen for providing the mCherry-GFP-LC3 construct and Dr. E. Tabares for providing the rabbit anti-HSV-1 glycoprotein B and D antibody. Henrike Kristen is the recipient of a UAM-CSIC International Excellence Campus research contract.

\section{Appendix A. Supplementary data}

Supplementary data related to this article can be found in the online version, at http://dx.doi.org/10.1016/j.neurobiolaging.2015. 06.014.

\section{References}

Aguilar, J.S., Devi-Rao, G.V., Rice, M.K., Sunabe, J., Ghazal, P., Wagner, E.K., 2006. Quantitative comparison of the HSV-1 and HSV-2 transcriptomes using DNA microarray analysis. Virology 348, 233-241.

Alvarez, G., Aldudo, J., Alonso, M., Santana, S., Valdivieso, F., 2012. Herpes simplex virus type 1 induces nuclear accumulation of hyperphosphorylated tau in neuronal cells. J. Neurosci. Res. 90, 1020-1029.

Berger, J.R., Houff, S., 2008. Neurological complications of herpes simplex virus type 2 infection. Arch. Neurol. 65, 596-600.

Bourgade, K., Garneau, H., Giroux, G., Le Page, A.Y., Bocti, C., Dupuis, G., Frost, E.H., Fulop Jr., T., 2014. beta-Amyloid peptides display protective activity against the human Alzheimer's disease-associated herpes simplex virus-1. Biogerontology $16,85-98$.

Braak, H., Braak, E., 1992. The human entorhinal cortex: normal morphology and lamina-specific pathology in various diseases. Neurosci. Res. 15, 6-31.

Bu, X.L., Yao, X.Q., Jiao, S.S., Zeng, F., Liu, Y.H., Xiang, Y., Liang, C.R., Wang, Q.H., Wang, X., Cao, H.Y., Yi, X., Deng, B., Liu, C.H., Xu, J., Zhang, L.L., Gao, C.Y., Xu, Z.Q., Zhang, M., Wang, L., Tan, X.L., Xu, X., Zhou, H.D., Wang, Y.J., 2014. A study on the association between infectious burden and Alzheimer's disease. Eur. J. Neurol. http://dx.doi.org/10.1111/ene.12477.

Cai, H., Wang, Y., McCarthy, D., Wen, H., Borchelt, D.R., Price, D.L., Wong, P.C., 2001. BACE1 is the major beta-secretase for generation of Abeta peptides by neurons. Nat. Neurosci. 4, 233-234.

Calle, A., Ugrinova, I., Epstein, A.L., Bouvet, P., Diaz, J.J., Greco, A., 2008. Nucleolin is required for an efficient herpes simplex virus type 1 infection. J. Virol. 82, $4762-4773$.

Carbone, I., Lazzarotto, T., Ianni, M., Porcellini, E., Forti, P., Masliah, E., Gabrielli, L., Licastro, F., 2014. Herpes virus in Alzheimer's disease: relation to progression of the disease. Neurobiol. Aging 35, 122-129.

Carrascosa, A.L., Santaren, J.F., Vinuela, E., 1982. Production and titration of African swine fever virus in porcine alveolar macrophages. J. Virol. Methods 3, 303-310.

De Chiara, G., Marcocci, M.E., Civitelli, L., Argnani, R., Piacentini, R., Ripoli, C., Manservigi, R., Grassi, C., Garaci, E., Palamara, A.T., 2010. APP processing induced by herpes simplex virus type 1 (HSV-1) yields several APP fragments in human and rat neuronal cells. PLoS One 5, e13989.

Delobel, P., Flament, S., Hamdane, M., Mailliot, C., Sambo, A.V., Begard, S., Sergeant, N., Delacourte, A., Vilain, J.P., Buee, L., 2002. Abnormal Tau phosphorylation of the Alzheimer-type also occurs during mitosis. J. Neurochem. 83, $412-420$.

Gobeil, P.A., Leib, D.A., 2012. Herpes simplex virus gamma34.5 interferes with autophagosome maturation and antigen presentation in dendritic cells. MBio. 3, e00267-e00312.
Goedert, M., Jakes, R., 1990. Expression of separate isoforms of human tau protein correlation with the tau pattern in brain and effects on tubulin polymerization. EMBO J. 9, 4225-4230.

Hemling, N., Roytta, M., Rinne, J., Pollanen, P., Broberg, E., Tapio, V., Vahlberg, T. Hukkanen, V., 2003. Herpesviruses in brains in Alzheimer's and Parkinson's diseases. Ann. Neurol. 54, 267-271.

Itzhaki, R.F., 2014. Herpes simplex virus type 1 and Alzheimer's disease: increasing evidence for a major role of the virus. Front. Aging Neurosci. 6, 202.

Jamieson, G.A., Maitland, N.J., Wilcock, G.K., Craske, J., Itzhaki, R.F., 1991. Latent herpes simplex virus type 1 in normal and Alzheimer's disease brains. J. Med. Virol. 33, 224-227.

Kabeya, Y., Mizushima, N., Ueno, T., Yamamoto, A., Kirisako, T., Noda, T. Kominami, E., Ohsumi, Y., Yoshimori, T., 2000. LC3, a mammalian homologue of yeast $\mathrm{Apg} 8 \mathrm{p}$, is localized in autophagosome membranes after processing. EMBO J. 19, 5720-5728.

Katan, M., Moon, Y.P., Paik, M.C., Sacco, R.L., Wright, C.B., Elkind, M.S., 2013. Infectious burden and cognitive function: the Northern Manhattan Study. Neurology $80,1209-1215$

Klionsky, D.J., Abdalla, F.C., Abeliovich, H., Abraham, R.T., Acevedo-Arozena, A. Adeli, K., Agholme, L., Agnello, M., Agostinis, P., Aguirre-Ghiso, J.A., Ahn, H.J. Ait-Mohamed, O., Ait-Si-Ali, S., Akematsu, T., Akira, S., Al-Younes, H.M., AlZeer, M.A., Albert, M.L., Albin, R.L., Alegre-Abarrategui, J., Aleo, M.F. Alirezaei, M., Almasan, A., Almonte-Becerril, M., Amano, A., Amaravadi, R., Amarnath, S., Amer, A.O., Andrieu-Abadie, N., Anantharam, V., Ann, D.K. Anoopkumar-Dukie, S., Aoki, H., Apostolova, N., Arancia, G., Aris, J.P., Asanuma, K., Asare, N.Y., Ashida, H., Askanas, V., Askew, D.S., Auberger, P., Baba, M., Backues, S.K., Baehrecke, E.H., Bahr, B.A., Bai, X.Y., Bailly, Y., Baiocchi, R., Baldini, G., Balduini, W., Ballabio, A., Bamber, B.A., Bampton, E.T. Banhegyi, G., Bartholomew, C.R., Bassham, D.C., Bast Jr., R.C., Batoko, H. Bay, B.H., Beau, I., Bechet, D.M., Begley, T.J., Behl, C., Behrends, C., Bekri, S., Bellaire, B., Bendall, LJ., Benetti, L., Berliocchi, L., Bernardi, H., Bernassola, F. Besteiro, S., Bhatia-Kissova, I., Bi, X., Biard-Piechaczyk, M., Blum, J.S., Boise, L.H. Bonaldo, P., Boone, D.L., Bornhauser, B.C., Bortoluci, K.R., Bossis, I., Bost, F. Bourquin, J.P., Boya, P., Boyer-Guittaut, M., Bozhkov, P.V., Brady, N.R. Brancolini, C., Brech, A., Brenman, J.E., Brennand, A., Bresnick, E.H., Brest, P., Bridges, D., Bristol, M.L., Brookes, P.S., Brown, E.J., Brumell, J.H., BrunettiPierri, N., Brunk, U.T., Bulman, D.E., Bultman, S.J., Bultynck, G., Burbulla, L.F., Bursch, W. Butchar, J.P., Buzgariu, W., Bydlowski, S.P. Cadwell, K., Cahova, M. Cai, D., Cai, J., Cai, Q., Calabretta, B., Calvo-Garrido, J., Camougrand, N. Campanella, M., Campos-Salinas, J., Candi, E., Cao, L., Caplan, A.B., Carding, S.R. Cardoso, S.M. Carew, J.S., Carlin, C.R., Carmignac, V., Carneiro, L.A., Carra, S. Caruso, R.A., Casari, G., Casas, C., Castino, R., Cebollero, E., Cecconi, F., Celli, J. Chaachouay, H., Chae, H.J., Chai, C.Y., Chan, D.C., Chan, E.Y., Chang, R.C., Che, C.M., Chen, C.C. Chen, G.C., Chen, G.Q., Chen, M., Chen, Q., Chen, S.S. Chen, W., Chen, X., Chen, X., Chen, X., Chen, Y.G., Chen, Y., Chen, Y., Chen, Y.J., Chen, Z., Cheng, A., Cheng, C.H., Cheng, Y., Cheong, H., Cheong, J.H., Cherry, S. Chess-Williams, R., Cheung, Z.H., Chevet, E., Chiang, H.L., Chiarelli, R., Chiba, T. Chin, L.S., Chiou, S.H., Chisari, F.V., Cho, C.H., Cho, D.H., Choi, A.M., Choi, D., Choi, K.S., Choi, M.E., Chouaib, S., Choubey, D., Choubey, V., Chu, C.T. Chuang, T.H., Chueh, S.H., Chun, T., Chwae, Y.J., Chye, M.L., Ciarcia, R. Ciriolo, M.R., Clague, M.J., Clark, R.S., Clarke, P.G., Clarke, R., Codogno, P., Coller, H.A., Colombo, M.I., Comincini, S., Condello, M., Condorelli, F., Cookson, M.R., Coombs, G.H., Coppens, I., Corbalan, R., Cossart, P., Costelli, P., Costes, S., Coto-Montes, A., Couve, E., Coxon, F.P., Cregg, J.M., Crespo, J.L., Cronje, M.J., Cuervo, A.M., Cullen, J.J., Czaja, M.J., D’Amelio, M., DarfeuilleMichaud, A., Davids, L.M., Davies, F.E., De Felici, M., de Groot, J.F., de Haan, C.A., De Martino, L., De Milito, A., De Tata, V., Debnath, J., Degterev, A., Dehay, B. Delbridge, L.M., Demarchi, F., Deng, Y.Z., Dengjel, J., Dent, P., Denton, D. Deretic, V., Desai, S.D., Devenish, R.J., Di Gioacchino, M., Di Paolo, G., Di Pietro, C., Diaz-Araya, G., Diaz-Laviada, I., Diaz-Meco, M.T., Diaz-Nido, J., Dikic, I., Dinesh-Kumar, S.P., Ding, W.X., Distelhorst, C.W., Diwan, A., DjavaheriMergny, M., Dokudovskaya, S., Dong, Z., Dorsey, F.C., Dosenko, V., Dowling, J.J., Doxsey, S., Dreux, M., Drew, M.E., Duan, Q., Duchosal, M.A., Duff, K., Dugail, I, Durbeej, M., Duszenko, M., Edelstein, C.L., Edinger, A.L., Egea, G., Eichinger, L. Eissa, N.T., Ekmekcioglu, S., El-Deiry, W.S., Elazar, Z., Elgendy, M., Ellerby, L.M. Eng, K.E., Engelbrecht, A.M., Engelender, S., Erenpreisa, J., Escalante, R., Esclatine, A., Eskelinen, E.L., Espert, L., Espina, V., Fan, H., Fan, J., Fan, Q.W., Fan, Z., Fang, S., Fang, Y., Fanto, M., Fanzani, A., Farkas, T., Farre, J.C., Faure, M. Fechheimer, M., Feng, C.G., Feng, J., Feng, Q., Feng, Y., Fesus, L., Feuer, R., Figueiredo-Pereira, M.E., Fimia, G.M., Fingar, D.C., Finkbeiner, S., Finkel, T. Finley, K.D., Fiorito, F., Fisher, E.A., Fisher, P.B., Flajolet, M., Florez-McClure, M.L., Florio, S., Fon, E.A., Fornai, F., Fortunato, F., Fotedar, R., Fowler, D.H., Fox, H.S. Franco, R., Frankel, L.B., Fransen, M., Fuentes, J.M., Fueyo, J., Fujii, J., Fujisaki, K., Fujita, E., Fukuda, M., Furukawa, R.H., Gaestel, M., Gailly, P., Gajewska, M., Galliot, B., Galy, V., Ganesh, S., Ganetzky, B., Ganley, I.G., Gao, F.B., Gao, G.F., Gao, J., Garcia, L., Garcia-Manero, G., Garcia-Marcos, M., Garmyn, M., Gartel, A.L. Gatti, E., Gautel, M., Gawriluk, T.R., Gegg, M.E., Geng, J., Germain, M. Gestwicki, J.E., Gewirtz, D.A., Ghavami, S., Ghosh, P., Giammarioli, A.M., Giatromanolaki, A.N., Gibson, S.B., Gilkerson, R.W., Ginger, M.L., Ginsberg, H.N., Golab, J., Goligorsky, M.S., Golstein, P., Gomez-Manzano, C., Goncu, E., Gongora, C., Gonzalez, C.D., Gonzalez, R., Gonzalez-Estevez, C., GonzalezPolo, R.A., Gonzalez-Rey, E., Gorbunov, N.V., Gorski, S., Goruppi, S., Gottlieb, R.A., Gozuacik, D., Granato, G.E., Grant, G.D., Green, K.N., Gregorc, A., Gros, F. Grose, C., Grunt, T.W., Gual, P., Guan, J.L., Guan, K.L., Guichard, S.M., Gukovskaya, A.S., Gukovsky, I., Gunst, J., Gustafsson, A.B., Halayko, A.J. 
Hale, A.N., Halonen, S.K., Hamasaki, M., Han, F., Han, T., Hancock, M.K., Hansen, M., Harada, H., Harada, M., Hardt, S.E., Harper, J.W., Harris, A.L., Harris, J., Harris, S.D., Hashimoto, M., Haspel, J.A., Hayashi, S., Hazelhurst, L.A., He, C., He, Y.W., Hebert, M.J., Heidenreich, K.A., Helfrich, M.H., Helgason, G.V., Henske, E.P., Herman, B., Herman, P.K., Hetz, C., Hilfiker, S., Hill, J.A., Hocking, L.J., Hofman, P., Hofmann, T.G., Hohfeld, J., Holyoake, T.L., Hong, M.H., Hood, D.A., Hotamisligil, G.S., Houwerzijl, E.J., Hoyer-Hansen, M., Hu, B., Hu, C.A., Hu, H.M., Hua, Y., Huang, C., Huang, J., Huang, S., Huang, W.P., Huber, T.B., Huh, W.K., Hung, T.H., Hupp, T.R., Hur, G.M., Hurley, J.B., Hussain, S.N., Hussey, P.J., Hwang, J.J., Hwang, S., Ichihara, A., Ilkhanizadeh, S., Inoki, K., Into, T., Iovane, V., Iovanna, J.L., Ip, N.Y., Isaka, Y., Ishida, H., Isidoro, C., Isobe, K., Iwasaki, A., Izquierdo, M., Izumi, Y., Jaakkola, P.M., Jaattela, M., Jackson, G.R., Jackson, W.T., Janji, B., Jendrach, M., Jeon, J.H., Jeung, E.B., Jiang, H., Jiang, H., Jiang, J.X., Jiang, M., Jiang, Q., Jiang, X., Jiang, X., Jimenez, A., Jin, M., Jin, S., Joe, C.O., Johansen, T., Johnson, D.E., Johnson, G.V., Jones, N.L., Joseph, B., Joseph, S.K., Joubert, A.M., Juhasz, G., Juillerat-Jeanneret, L., Jung, C.H., Jung, Y.K., Kaarniranta, K. Kaasik, A., Kabuta, T. Kadowaki, M. Kagedal, K., Kamada, Y., Kaminskyy, V.O., Kampinga, H.H., Kanamori, H., Kang, C., Kang, K.B., Kang, K.I., Kang, R., Kang, Y.A., Kanki, T., Kanneganti, T.D., Kanno, H., Kanthasamy, A.G., Kanthasamy, A., Karantza, V., Kaushal, G.P., Kaushik, S., Kawazoe, Y., Ke, P.Y., Kehrl, J.H., Kelekar, A., Kerkhoff, C., Kessel, D.H., Khalil, H., Kiel, J.A., Kiger, A.A., Kihara, A., Kim, D.R., Kim, D.H., Kim, D.H., Kim, E.K., Kim, H.R., Kim, J.S., Kim, J.H., Kim, J.C., Kim, J.K., Kim, P.K., Kim, S.W., Kim, Y.S., Kim, Y., Kimchi, A., Kimmelman, A.C., King, J.S., Kinsella, T.J., Kirkin, V., Kirshenbaum, L.A., Kitamoto, K., Kitazato, K., Klein, L., Klimecki, W.T., Klucken, J., Knecht, E., Ko, B.C., Koch, J.C., Koga, H., Koh, J.Y., Koh, Y.H., Koike, M., Komatsu, M., Kominami, E., Kong, H.J., Kong, W.J., Korolchuk, V.I., Kotake, Y., Koukourakis, M.I., Kouri Flores, J.B., Kovacs, A.L., Kraft, C., Krainc, D., Kramer, H., Kretz-Remy, C., Krichevsky, A.M., Kroemer, G., Kruger, R., Krut, O., Ktistakis, N.T., Kuan, C.Y., Kucharczyk, R., Kumar, A., Kumar, R., Kumar, S., Kundu, M., Kung, H.J., Kurz, T., Kwon, H.J., La Spada, A.R., Lafont, F. Lamark, T., Landry, J., Lane, J.D., Lapaquette, P., Laporte, J.F., Laszlo, L., Lavandero, S., Lavoie, J.N., Layfield, R., Lazo, P.A., Le, W., Le Cam, L., Ledbetter, D.J., Lee, A.J., Lee, B.W., Lee, G.M., Lee, J., Lee, J.H., Lee, M., Lee, M.S., Lee, S.H., Leeuwenburgh, C., Legembre, P., Legouis, R., Lehmann, M., Lei, H.Y., Lei, Q.Y., Leib, D.A., Leiro, J., Lemasters, J.J., Lemoine, A., Lesniak, M.S., Lev, D., Levenson, V.V., Levine, B., Levy, E., Li, F., Li, J.L., Li, L., Li, S., Li, W., Li, X.J., Li, Y.B., Li, Y.P., Liang, C., Liang, Q., Liao, Y.F., Liberski, P.P., Lieberman, A., Lim, H.J, Lim, K.L., Lim, K., Lin, C.F. Lin, F.C., Lin, J., Lin, J.D., Lin, K., Lin, W.W., Lin, W.C., Lin, Y.L., Linden, R., Lingor, P., Lippincott-Schwartz, J., Lisanti, M.P., Liton, P.B., Liu, B., Liu, C.F., Liu, K., Liu, L., Liu, Q.A., Liu, W., Liu, Y.C., Liu, Y. Lockshin, R.A., Lok, C.N., Lonial, S., Loos, B., Lopez-Berestein, G., LopezOtin, C., Lossi, L., Lotze, M.T., Low, P., Lu, B., Lu, B., Lu, B., Lu, Z., Luciano, F., Lukacs, N.W., Lund, A.H., Lynch-Day, M.A., Ma, Y., Macian, F., MacKeigan, J.P., Macleod, K.F., Madeo, F., Maiuri, L., Maiuri, M.C., Malagoli, D., Malicdan, M.C. Malorni, W. Man, N., Mandelkow, E.M., Manon, S., Manov, I., Mao, K., Mao, X. Mao, Z., Marambaud, P., Marazziti, D., Marcel, Y.L., Marchbank, K., Marchetti, P., Marciniak, S.J., Marcondes, M., Mardi, M., Marfe, G., Marino, G., Markaki, M., Marten, M.R., Martin, S.J., Martinand-Mari, C., Martinet, W., MartinezVicente, M., Masini, M., Matarrese, P., Matsuo, S., Matteoni, R., Mayer, A., Mazure, N.M., McConkey, D.J., McConnell, M.J., McDermott, C., McDonald, C., McInerney, G.M., McKenna, S.L., McLaughlin, B., McLean, P.J., McMaster, C.R., McQuibban, G.A., Meijer, A.J., Meisler, M.H., Melendez, A., Melia, T.J., Melino, G. Mena, M.A., Menendez, J.A., Menna-Barreto, R.F., Menon, M.B., Menzies, F.M., Mercer, C.A., Merighi, A., Merry, D.E., Meschini, S., Meyer, C.G., Meyer, T.F., Miao, C.Y., Miao, J.Y., Michels, P.A., Michiels, C., Mijaljica, D., Milojkovic, A., Minucci, S., Miracco, C., Miranti, C.K., Mitroulis, I., Miyazawa, K., Mizushima, N., Mograbi, B., Mohseni, S., Molero, X., Mollereau, B., Mollinedo, F., Momoi, T., Monastyrska, I., Monick, M.M., Monteiro, M.J., Moore, M.N., Mora, R., Moreau, K., Moreira, P.I., Moriyasu, Y., Moscat, J., Mostowy, S., Mottram, J.C., Motyl, T., Moussa, C.E., Muller, S., Muller, S., Munger, K., Munz, C., Murphy, L.O., Murphy, M.E., Musaro, A., Mysorekar, I., Nagata, E., Nagata, K., Nahimana, A., Nair, U., Nakagawa, T., Nakahira, K., Nakano, H., Nakatogawa, H., Nanjundan, M., Naqvi, N.I., Narendra, D.P., Narita, M., Navarro, M., Nawrocki, S.T., Nazarko, T.Y., Nemchenko, A., Netea, M.G., Neufeld, T.P., Ney, P.A., Nezis, I.P., Nguyen, H.P., Nie, D., Nishino, I., Nislow, C., Nixon, R.A., Noda, T., Noegel, A.A., Nogalska, A., Noguchi, S., Notterpek, L., Novak, I., Nozaki, T., Nukina, N., Nurnberger, T., Nyfeler, B., Obara, K., Oberley, T.D., Oddo, S., Ogawa, M., Ohashi, T., Okamoto, K., Oleinick, N.L., Oliver, F.J., Olsen, L.J., Olsson, S., Opota, O., Osborne, T.F., Ostrander, G.K., Otsu, K., Ou, J.H., Ouimet, M., Overholtzer, M., Ozpolat, B., Paganetti, P., Pagnini, U., Pallet, N., Palmer, G.E., Palumbo, C., Pan, T., Panaretakis, T., Pandey, U.B., Papackova, Z., Papassideri, I., Paris, I., Park, J., Park, O.K., Parys, J.B., Parzych, K.R., Patschan, S., Patterson, C., Pattingre, S., Pawelek, J.M., Peng, J., Perlmutter, D.H., Perrotta, I., Perry, G., Pervaiz, S., Peter, M., Peters, G.J., Petersen, M., Petrovski, G., Phang, J.M., Piacentini, M., Pierre, P., Pierrefite-Carle, V., Pierron, G., Pinkas-Kramarski, R., Piras, A., Piri, N., Platanias, L.C. Poggeler, S., Poirot, M., Poletti, A., Pous, C., Pozuelo-Rubio, M., Praetorius-Ibba, M., Prasad, A., Prescott, M., Priault, M., Produit-Zengaffinen, N., Progulske-Fox, A., Proikas-Cezanne, T., Przedborski, S., Przyklenk, K., Puertollano, R., Puyal, J., Qian, S.B., Qin, L., Qin, Z.H., Quaggin, S.E., Raben, N., Rabinowich, H., Rabkin, S.W., Rahman, I., Rami, A., Ramm, G., Randall, G., Randow, F., Rao, V.A., Rathmell, J.C., Ravikumar, B., Ray, S.K., Reed, B.H., Reed, J.C., Reggiori, F., Regnier-Vigouroux, A., Reichert, A.S., Reiners Jr., J.J., Reiter, R.J., Ren, J., Revuelta, J.L., Rhodes, C.J., Ritis, K., Rizzo, E., Robbins, J., Roberge, M., Roca, H., Roccheri, M.C., Rocchi, S., Rodemann, H.P., Rodriguez de Cordoba, S., Rohrer, B., Roninson, I.B., Rosen, K., Rost-Roszkowska, M.M.,
Rouis, M., Rouschop, K.M., Rovetta, F., Rubin, B.P., Rubinsztein, D.C. Ruckdeschel, K., Rucker, E.B., 3rd, Rudich, A., Rudolf, E., Ruiz-Opazo, N., Russo, R., Rusten, T.E., Ryan, K.M., Ryter, S.W., Sabatini, D.M., Sadoshima, J., Saha, T., Saitoh, T., Sakagami, H., Sakai, Y., Salekdeh, G.H., Salomoni, P., Salvaterra, P.M., Salvesen, G., Salvioli, R., Sanchez, A.M., Sanchez-Alcazar, J.A. Sanchez-Prieto, R., Sandri, M., Sankar, U., Sansanwal, P., Santambrogio, L. Saran, S., Sarkar, S., Sarwal, M., Sasakawa, C. Sasnauskiene, A., Sass, M., Sato, K. Sato, M., Schapira, A.H., Scharl, M., Schatzl, H.M., Scheper, W., Schiaffino, S. Schneider, C., Schneider, M.E., Schneider-Stock, R., Schoenlein, P.V., Schorderet, D.F., Schuller, C., Schwartz, G.K., Scorrano, L., Sealy, L., Seglen, P.O., Segura-Aguilar, J., Seiliez, I., Seleverstov, O., Sell, C., Seo, J.B., Separovic, D. Setaluri, V., Setoguchi, T., Settembre, C., Shacka, J.J., Shanmugam, M. Shapiro, I.M., Shaulian, E., Shaw, R.J., Shelhamer, J.H., Shen, H.M., Shen, W.C. Sheng, Z.H., Shi, Y., Shibuya, K., Shidoji, Y., Shieh, J.J., Shih, C.M., Shimada, Y., Shimizu, S., Shintani, T., Shirihai, O.S., Shore, G.C., Sibirny, A.A., Sidhu, S.B., Sikorska, B., Silva-Zacarin, E.C., Simmons, A., Simon, A.K., Simon, H.U., Simone, C. Simonsen, A., Sinclair, D.A., Singh, R. Sinha, D., Sinicrope, F.A. Sirko, A., Siu, P.M., Sivridis, E., Skop, V., Skulachev, V.P., Slack, R.S., Smaili, S.S. Smith, D.R., Soengas, M.S., Soldati, T., Song, X., Sood, A.K., Soong, T.W., Sotgia, F., Spector, S.A., Spies, C.D., Springer, W., Srinivasula, S.M., Stefanis, L., Steffan, J.S. Stendel, R., Stenmark, H., Stephanou, A., Stern, S.T., Sternberg, C., Stork, B. Stralfors, P., Subauste, C.S., Sui, X., Sulzer, D., Sun, J., Sun, S.Y., Sun, Z.J., Sung, J.J., Suzuki, K., Suzuki, T., Swanson, M.S., Swanton, C., Sweeney, S.T., Sy, L.K., Szabadkai, G., Tabas, I., Taegtmeyer, H., Tafani, M., Takacs-Vellai, K., Takano, Y. Takegawa, K., Takemura, G., Takeshita, F., Talbot, N.J., Tan, K.S., Tanaka, K. Tanaka, K., Tang, D., Tang, D., Tanida, I., Tannous, B.A., Tavernarakis, N. Taylor, G.S., Taylor, G.A., Taylor, J.P., Terada, L.S., Terman, A., Tettamanti, G., Thevissen, K., Thompson, C.B., Thorburn, A., Thumm, M., Tian, F., Tian, Y., Tocchini-Valentini, G., Tolkovsky, A.M., Tomino, Y., Tonges, L., Tooze, S.A. Tournier, C., Tower, J., Towns, R., Trajkovic, V., Travassos, L.H., Tsai, T.F., Tschan, M.P., Tsubata, T., Tsung, A., Turk, B., Turner, L.S., Tyagi, S.C., Uchiyama, Y. Ueno, T., Umekawa, M., Umemiya-Shirafuji, R., Unni, V.K., Vaccaro, M.I., Valente, E.M., Van den Berghe, G., van der Klei, I.J., van Doorn, W., van Dyk, L.F., van Egmond, M., van Grunsven, L.A., Vandenabeele, P., Vandenberghe, W.P., Vanhorebeek, I., Vaquero, E.C., Velasco, G., Vellai, T., Vicencio, J.M., Vierstra, R.D. Vila, M., Vindis, C., Viola, G., Viscomi, M.T., Voitsekhovskaja, O.V., von Haefen, C., Votruba, M., Wada, K., Wade-Martins, R., Walker, C.L., Walsh, C.M., Walter, J., Wan, X.B., Wang, A., Wang, C., Wang, D., Wang, F., Wang, F., Wang, G., Wang, H., Wang, H.G., Wang, H.D., Wang, J., Wang, K., Wang, M., Wang, R.C., Wang, X. Wang, X., Wang, Y.J., Wang, Y., Wang, Z., Wang, Z.C., Wang, Z., Wansink, D.G. Ward, D.M., Watada, H., Waters, S.L., Webster, P., Wei, L., Weihl, C.C. Weiss, W.A., Welford, S.M., Wen, L.P., Whitehouse, C.A., Whitton, J.L. Whitworth, A.J., Wileman, T., Wiley, J.W., Wilkinson, S., Willbold, D. Williams, R.L., Williamson, P.R., Wouters, B.G., Wu, C., Wu, D.C., Wu, W.K. Wyttenbach, A., Xavier, R.J., Xi, Z., Xia, P., Xiao, G., Xie, Z., Xie, Z., Xu, D.Z., Xu, J. Xu, L., Xu, X., Yamamoto, A., Yamamoto, A., Yamashina, S., Yamashita, M., Yan, X. Yanagida, M., Yang, D.S., Yang, E., Yang, J.M., Yang, S.Y., Yang, W., Yang, W.Y., Yang, Z., Yao, M.C., Yao, T.P., Yeganeh, B., Yen, W.L., Yin, J.J., Yin, X.M., Yoo, O.J., Yoon, G., Yoon, S.Y., Yorimitsu, T., Yoshikawa, Y., Yoshimori, T., Yoshimoto, K., You, H.J., Youle, R.J., Younes, A., Yu, L., Yu, L., Yu, S.W., Yu, W.H., Yuan, Z.M., Yue, Z., Yun, C.H., Yuzaki, M., Zabirnyk, O., Silva-Zacarin, E., Zacks, D. Zacksenhaus, E., Zaffaroni, N., Zakeri, Z., Zeh 3rd, H.J., Zeitlin, S.O., Zhang, H., Zhang, H.L., Zhang, J., Zhang, J.P., Zhang, L., Zhang, L., Zhang, M.Y., Zhang, X.D. Zhao, M., Zhao, Y.F., Zhao, Y., Zhao, Z.J., Zheng, X., Zhivotovsky, B., Zhong, Q., Zhou, C.Z., Zhu, C., Zhu, W.G., Zhu, X.F., Zhu, X., Zhu, Y., Zoladek, T., Zong, W.X., Zorzano, A., Zschocke, J., Zuckerbraun, B., 2012. Guidelines for the use and interpretation of assays for monitoring autophagy. Autophagy 8, 445-544.

Koelle, D.M., Corey, L., 2008. Herpes simplex: insights on pathogenesis and possible vaccines. Annu. Rev. Med. 59, 381-395.

LaFerla, F.M., Green, K.N., Oddo, S., 2007. Intracellular amyloid-beta in Alzheimer's disease. Nat. Rev. Neurosci. 8, 499-509.

Letenneur, L., Peres, K., Fleury, H., Garrigue, I., Barberger-Gateau, P., Helmer, C., Orgogozo, J.M., Gauthier, S., Dartigues, J.F., 2008. Seropositivity to herpes simplex virus antibodies and risk of Alzheimer's disease: a population-based cohort study. PLoS One 3, e3637.

Lin, W.R., Wozniak, M.A., Cooper, R.J., Wilcock, G.K., Itzhaki, R.F., 2002. Herpesviruses in brain and Alzheimer's disease. J. Pathol. 197, 395-402.

Lovestone, S., Reynolds, C.H., 1997. The phosphorylation of tau: a critical stage in neurodevelopment and neurodegenerative processes. Neuroscience 78, 309-324.

Lovheim, H., Gilthorpe, J., Adolfsson, R., Nilsson, L.G., Elgh, F., 2014. Reactivated herpes simplex infection increases the risk of Alzheimer's disease. Alzheimer's Dement. 11, 593-599.

Martin, C., Aguila, B., Araya, P., Vio, K., Valdivia, S., Zambrano, A., Concha, M.I. Otth, C., 2014. Inflammatory and neurodegeneration markers during asymptomatic HSV-1 reactivation. J. Alzheimer's Dis. 39, 849-859.

Miklossy, J., 2011. Emerging roles of pathogens in Alzheimer disease. Expert Rev. Mol. Med. 13, e30.

Mohni, K.N., Livingston, C.M., Cortez, D., Weller, S.K., 2010. ATR and ATRIP are recruited to herpes simplex virus type 1 replication compartments even though ATR signaling is disabled. J. Virol. 84, 12152-12164.

Moon, S.M., Kim, T., Lee, E.M., Kang, J.K., Lee, S.A., Choi, S.H., 2014. Comparison of clinical manifestations, outcomes and cerebrospinal fluid findings between herpes simplex type 1 and type 2 central nervous system infections in adults. J. Med. Virol. 86, 1766-1771. 
Nixon, R.A., Wegiel, J., Kumar, A., Yu, W.H., Peterhoff, C., Cataldo, A., Cuervo, A.M., 2005. Extensive involvement of autophagy in Alzheimer disease: an immunoelectron microscopy study. J. Neuropathol. Exp. Neurol. 64, 113-122.

Nixon, R.A., Yang, D.S., 2011. Autophagy failure in Alzheimer's disease-locating the primary defect. Neurobiol. Dis. 43, 38-45.

Pankiv, S., Clausen, T.H., Lamark, T., Brech, A., Bruun, J.A., Outzen, H., Outzen, H., Overvatn, A., Bjorkoy, G., Johansen, T., 2007. p62/SQSTM1 binds directly to Atg8/ LC3 to facilitate degradation of ubiquitinated protein aggregates by autophagy. J. Biol. Chem. 282, 24131-24145.

Piacentini, R. De Chiara, G Li Puma, D.D Ripoli, C Marcocci, ME Garaci, E. Palamara, A.T., Grassi, C., 2014. HSV-1 and Alzheimer's disease: more than a hypothesis. Front. Pharmacol. 5, 97.

Porcellini, E., Carbone, I., Ianni, M., Licastro, F., 2010. Alzheimer's disease gene signature says: beware of brain viral infections. Immun. Ageing 7, 16 .

Puig, B., Rey, M.J., Ferrer, I., 2005. Individual and regional variations of phospho-tau species in progressive supranuclear palsy. Acta Neuropathol. 110, 261-268.

Recuero, M., Serrano, E., Bullido, M.J., Valdivieso, F., 2004. Abeta production as consequence of cellular death of a human neuroblastoma overexpressing APP. FEBS Lett. 570, 114-118.

Santana, S., Bullido, M.J., Recuero, M., Valdivieso, F., Aldudo, J., 2012a. Herpes simplex virus type I induces an incomplete autophagic response in human neuroblastoma cells. J. Alzheimer's Dis. 30, 815-831.

Santana, S., Recuero, M., Bullido, M.J., Valdivieso, F., Aldudo, J., 2012b. Herpes simplex virus type I induces the accumulation of intracellular beta-amyloid in autophagic compartments and the inhibition of the non-amyloidogenic pathway in human neuroblastoma cells. Neurobiol. Aging 33, 430.e19-430.e33.

Santpere, G., Puig, B., Ferrer, I., 2006. Low molecular weight species of tau in Alzheimer's disease are dependent on tau phosphorylation sites but not on delayed post-mortem delay in tissue processing. Neurosci. Lett. 399, 106-110.

Schott, J.M., Revesz, T., 2013. Inflammation in Alzheimer's disease: insights from immunotherapy. Brain 136 (Pt 9), 2654-2656.

Soscia, S.J., Kirby, J.E., Washicosky, K.J., Tucker, S.M., Ingelsson, M., Hyman, B., Burton, M.A., Goldstein, L.E., Duong, S., Tanzi, R.E., Moir, R.D., 2010. The Alzheimer's disease-associated amyloid beta-protein is an antimicrobial peptide. PLoS One 5, e9505.
Steiner, I., Benninger, F., 2013. Update on herpes virus infections of the nervous system. Curr. Neurol. Neurosci. Rep. 13, 414.

Strandberg T.E. Pitkala, K.H., Linnavuori, K.H., Tilvis, R.S., 2003. Impact of viral and bacterial burden on cognitive impairment in elderly persons with cardiovascular diseases. Stroke 34, 2126-2131.

Strandberg, T.E., Pitkala, K., Eerola, J., Tilvis, R., Tienari, P.J., 2005. Interaction of herpesviridae, APOE gene, and education in cognitive impairment. Neurobiol. Aging 26, 1001-1004

Sultan, A., Nesslany, F., Violet, M., Begard, S., Loyens, A., Talahari, S., Mansuroglu, Z., Marzin, D., Sergeant, N., Humez, S., Colin, M., Bonnefoy, E., Buee, L., Galas, M.C. 2011. Nuclear tau, a key player in neuronal DNA protection. J. Biol. Chem. 286 $4566-4575$.

Tanzi, R.E., 2012. The genetics of Alzheimer disease. Cold Spring Harb. Perspect. Med. 2.

White, M.R., Kandel, R., Tripathi, S., Condon, D., Qi, L., Taubenberger, J. Hartshorn, K.L., 2014. Alzheimer's associated beta-amyloid protein inhibits influenza A virus and modulates viral interactions with phagocytes. PLoS One 9, e101364.

Wilcock, D., Lane, D.P., 1991. Localization of p53, retinoblastoma and host replication proteins at sites of viral replication in herpes-infected cells. Nature 349, 429-431.

Wozniak, M.A., Frost, A.L., Itzhaki, R.F., 2009a. Alzheimer's disease-specific tau phosphorylation is induced by herpes simplex virus type 1. J. Alzheimer's Dis. $16,341-350$.

Wozniak, M.A., Frost, A.L., Preston, C.M., Itzhaki, R.F., 2011. Antivirals reduce the formation of key Alzheimer's disease molecules in cell cultures acutely infected with herpes simplex virus type 1. PLoS One 6, e25152.

Wozniak, M.A., Itzhaki, R.F., Shipley, S.J., Dobson, C.B., 2007. Herpes simplex virus infection causes cellular beta-amyloid accumulation and secretase upregulation. Neurosci. Lett. 429, 95-100.

Wozniak, M.A. Mee, A.P. Itzhaki, R.F., 2009b. Herpes simplex virus type 1 DNA is located within Alzheimer's disease amyloid plaques. J. Pathol. 217, 131-138.

Zambrano, A., Solis, L., Salvadores, N., Cortes, M., Lerchundi, R., Otth, C., 2008 Neuronal cytoskeletal dynamic modification and neurodegeneration induced by infection with herpes simplex virus type 1. J. Alzheimer's Dis. 14, 259-269. 